\title{
Effect of time interval from insemination to first cleavage on the developmental characteristics, sex ratio and pregnancy rate after transfer of bovine embryos
}

\author{
P. Lonergan ${ }^{1}$, H. Khatir ${ }^{2}$, F. Piumi ${ }^{3}$, D. Rieger ${ }^{4}$, P. Humblot ${ }^{3}$ and M. P. Boland ${ }^{1}$ \\ ${ }^{1}$ Department of Animal Science and Production, University College Dublin, Lyons Research Farm, Newcastle, County Dublin, Ireland; \\ ${ }^{2}$ INRA-PRMD, 37380 Nouzilly, France; ${ }^{3}$ UNCEIA, Services Techniques, 13, rue Jouet, BP 65, 94703 Maisons Alfort, France; and ${ }^{4}$ Animal \\ Biotechnology Embryo Laboratory, Department of Biomedical Sciences, University of Guelph, Guelph, Ontario, Canada N1G 2W1
}

\begin{abstract}
In vitro produced bovine zygotes show substantial variation in the time required to complete the first cell cycle and in their in vitro development potential. A number of reports have highlighted the fact that the fastest developing embryos in vitro are most likely to be comparable with their in vivo counterparts. At $24 \mathrm{~h}$ after IVF, presumptive zygotes were cultured in droplets of synthetic oviduct fluid medium. Droplets were examined at regular intervals and all cleaved embryos at each time point were transferred into new droplets and cultured separately for the duration of the experiment. All uncleaved zygotes were returned to the incubator and re-examined at the successive time points until $48 \mathrm{~h}$ after insemination, at which time the remaining uncleaved oocytes were retained as a group. A representative number of day 7 blastocysts from zygotes that had cleaved by 30 or $36 \mathrm{~h}$ were transferred to synchronized recipients and pregnancy was diagnosed by ultrasonography at day 35 . Glucose and glutamine metabolism was examined in zygotes and blastocysts and compared retrospectively with time of first cleavage. A representative number of blastocysts from each of the cleavage groups was sexed using PCR. Data were analysed by chi-squared and regression analysis. Development to the blastocyst stage decreased as the time from insemination to first cleavage increased $(r=0.97, P<0.03)$. There was no difference in blastocyst hatching, number of blastocyst cells or pregnancy rate between the 30 and $36 \mathrm{~h}$ groups. The overall sex ratio was $62 \%$ males $(n=258$, $P<0.0001)$ and was not different in the 30 and $36 \mathrm{~h}$ groups $(61 \%, n=155$ versus $63 \%$, $n=95$, respectively). These results indicate that although time of first cleavage has a major influence on the probability of an embryo developing to the blastocyst stage, once that stage is attained, subsequent developmental characteristics are unrelated to the time of first cleavage.
\end{abstract}

\section{Introduction}

The factors that determine whether an oocyte develops to the blastocyst stage after fertilization are not yet fully understood. Despite wide variation in the techniques of in vitro bovine embryo production, blastocyst rates tend to plateau at about $40 \%$ of oocytes submitted to in vitro maturation (Gordon, 1994). It is becoming increasingly clear that although suboptimal culture conditions undoubtedly contribute to this poor embryo yield, the developmental rates obtainable in vitro are also related to the intrinsic quality of the oocyte. There are several lines of evidence in support of this idea. For example, oocytes derived from large follicles (that is, in the terminal stages of follicular development) develop better in culture than those derived

Received 4 December 1998. from small follicles (Pavlok et al., 1992; Lonergan et al., 1994). In addition, zygotes obtained after in vivo maturation and fertilization are superior in terms of development in culture to their in vitro counterparts (Marquant-Le Guienne et al., 1989; McCaffrey et al., 1991).

In vitro produced bovine embryos show substantial variation in both the time required to complete the first cell cycle and in their in vitro development potential. Various reports have highlighted the fact that the fastest developing embryos in vitro are more likely to develop to the morula and blastocyst stages (Lonergan et al., 1992; Van Soom et al., 1992; Xu et al., 1992; Yadav et al., 1993; Grisart $e t$ al., 1994; Plante et al., 1994; Itagaki et al., 1997; Kubisch et al., 1998). Moreover, those blastocysts that form early appear to have a greater likelihood of providing live offspring after transfer (Hasler et al., 1995). The mechanisms controlling this development are almost certainly in place in the oocyte before fertilization. For 
example, oocytes extruding the first polar body earliest during in vitro maturation have a higher probability of reaching the blastocyst stage (Dominko and First, 1992; van der Westerlaken et al., 1994). Thus, the speed of development is directly related to the development potential and may be an important parameter in selecting embryos that have the greatest likelihood of establishing and maintaining a pregnancy after transfer.

This situation is not unique to the bovine embryo. A relationship between the kinetics of early embryonic cleavage and subsequent development has been observed in mouse (Warner et al., 1998), hamster (McKiernan and Bavister, 1994), rhesus monkey (Bavister et al., 1983), buffalo (Totey et al., 1996) and human (Lelaidier et al., 1995; Sakkas et al., 1998; Shoukir et al., 1998) embryos. These kinetics of development have been related to the sex of the embryo and faster developing embryos tend to be males (Avery et al., 1989, 1991; Xu et al., 1992; Yadav et al., 1993; Carvalho et al., 1996), although this has not been observed in all cases (Grisart et al., 1995; Lonergan et al., 1995; Kaminski et al., 1996). This difference in developmental rates between male and female embryos has been attributed to differences in metabolic activity in these embryos (Tiffen et al., 1991; Ray et al., 1995).

Although there is evidence of an effect of time of cleavage on subsequent development to the blastocyst stage in cattle, there is a lack of information on the ability of these blastocysts to establish and maintain a pregnancy. The objectives of this series of experiments were: (i) to examine the relationship between time of first cleavage and formation rates and sex of the resulting blastocysts; (ii) to examine the embryo metabolism rates according to cleavage times; and (iii) to determine pregnancy rates in synchronized recipients after non-surgical transfer of blastocysts originating from 'early cleaving' or 'late cleaving' embryos.

\section{Materials and Methods}

\section{Oocyte collection and in vitro maturation (IVM), fertilization (IVF) and culture (IVC)}

Chemicals were purchased from Sigma Chemical Co. (St Louis, MO) unless otherwise indicated. A stock solution of $10 \mu \mathrm{g}$ epidermal growth factor (EGF) $\mathrm{ml}^{-1}$ was prepared, aliquoted and stored at $-20^{\circ} \mathrm{C}$ until use.

Cumulus-oocyte complexes (COCs) were obtained by aspiration of follicles $2-8 \mathrm{~mm}$ in diameter from the ovaries of cows killed at an abattoir. After four washes in modified PBS supplemented with $36 \mu \mathrm{g}$ pyruvate $\mathrm{ml}^{-1}, 50 \mu \mathrm{g}$ gentamycin $\mathrm{ml}^{-1}$ and $0.5 \mathrm{mg}$ bovine serum albumin (BSA) $\mathrm{ml}^{-1}$ (Sigma fraction V, catalogue number A-9647), groups of approximately $50 \mathrm{COCs}$ were placed in $500 \mu \mathrm{l}$ maturation medium in four-well dishes (Nunc, Roskilde) and cultured for $24 \mathrm{~h}$ at $39^{\circ} \mathrm{C}$ in an atmosphere of $5 \% \mathrm{CO}_{2}$ in air with maximum humidity. The maturation medium was medium 199 supplemented with $10 \mathrm{ng} \mathrm{EGF} \mathrm{ml}^{-1}$ (Lonergan et al., 1996).

For IVF, COCs were washed four times in PBS and then in fertilization medium before groups of 50 were transferred into four-well plates containing $250 \mu \mathrm{l}$ fertilization medium (Tyrode's medium with 25 mmol bicarbonate $\mathrm{l}^{-1}, 22 \mathrm{mmol}$ sodium lactate $\mathrm{l}^{-1}, 1 \mathrm{mmol}$ sodium pyruvate $\mathrm{l}^{-1}, 6 \mathrm{mg}$ fatty acid-free BSA ml-1 and $10 \mu \mathrm{g}$ heparin-sodium salt ml-1 (184 units heparin $\mathrm{mg}^{-1}$ ), Calbiochem, San Diego, CA) per well. Motile spermatozoa (Dovea AI Station, Mallow, Ireland) were obtained by centrifugation of frozen-thawed spermatozoa on a discontinuous Percoll (Pharmacia, Uppsala) density gradient $(2.5 \mathrm{ml} 45 \%$ (v/v) Percoll over $2.5 \mathrm{ml} 90 \%$ $(\mathrm{v} / \mathrm{v})$ Percoll) for $20 \mathrm{~min}$ at $700 \mathrm{~g}$ at room temperature. Viable spermatozoa collected at the bottom of the $90 \%$ fraction were washed in Hepes-buffered Tyrode's and pelleted by centrifugation at $100 \mathrm{~g}$ for $10 \mathrm{~min}$. Spermatozoa were counted in a haemocytometer and diluted in the appropriate volume of Tyrode's albumin lactate pyruvate (TALP) to give a concentration of $2 \times 10^{6}$ spermatozoa ml ${ }^{-1}$. A $250 \mu$ aliquot of this suspension was added to each fertilization well to obtain a final concentration of $1 \times 10^{6}$ spermatozoa ml $^{-1}$. Plates were incubated for $24 \mathrm{~h}$ in $5 \% \mathrm{CO}_{2}$ in humidified air at $39^{\circ} \mathrm{C}$. In the experiments described below, the time of addition of the spermatozoa to the oocytes is defined as the time of insemination.

Embryo culture was carried out in modified synthetic oviduct fluid medium (SOF) under mineral oil in a humidified atmosphere of $5 \% \mathrm{CO}_{2}, 5 \% \mathrm{O}_{2}$ and $90 \% \mathrm{~N}_{2}$ at $39^{\circ} \mathrm{C}$ (Carolan et al., 1995). At $24 \mathrm{~h}$ after insemination, presumptive zygotes were denuded of cumulus cells by vortexing for 2 $\mathrm{min}$ in $2 \mathrm{ml}$ PBS. The zygotes were washed four times in PBS and then in SOF before they were transferred to $25 \mu \mathrm{l}$ culture droplets. After $24 \mathrm{~h}$ in culture (that is, $48 \mathrm{~h}$ after insemination), $10 \%(\mathrm{v} / \mathrm{v})$ fetal calf serum (FCS) was added to the droplets. Blastocyst rates were recorded at day 8 after insemination.

These conditions have routinely resulted in 90-95\% maturation, $85-90 \%$ fertilization and $35-45 \%$ blastocyst formation for cattle oocytes (Carolan et al., 1995; Lonergan et al., 1996).

\section{Experiment 1: effect of time of first cleavage on subsequent development}

In a preliminary study (Expt 1a, three replicates), 577 COCs were used. After IVM and IVF, presumptive zygotes were cultured in vitro in droplets of SOF at $24 \mathrm{~h}$ after insemination. The drops were examined at $30,36,42$ and $48 \mathrm{~h}$ after insemination. At each time point, all embryos with two or more distinct blastomeres were transferred into new IVC droplets and were cultured separately for the duration of the experiment. All uncleaved presumptive zygotes were returned to the incubator and re-examined at the successive time points until $48 \mathrm{~h}$ after insemination, at which time those still uncleaved were retained as a group.

For estimation of the total number of cells, blastocysts were placed on a slide, air-dried, and fixed in $100 \%$ ethanol overnight. They were subsequently stained using Hoechst $33342\left(10 \mathrm{mg} \mathrm{ml}^{-1}\right.$ in $2.3 \%(\mathrm{w} / \mathrm{v})$ sodium citrate) and visualized with an epifluorescence microscope (Zeiss, Oberkochen).

This experiment was repeated (Expt 1b, three replicates) 
except that the zygotes $(n=839)$ were examined at more frequent intervals $(27,30,33,36,42,48 \mathrm{~h}$ after insemination) to examine the effect of time of cleavage in more detail. At each time point, embryos that had cleaved were removed and cultured separately for the remainder of the culture period as described for Expt 1a.

\section{Experiment 2: measurement of embryo metabolism}

Two separate metabolism studies were conducted. In Expt 2a (three replicates), presumptive zygotes were removed from culture at $21 \mathrm{~h}$ after insemination (that is, before the first cleavage division). Any remaining cumulus cells were removed and the zygotes were washed twice in metabolic measurement medium (see below) before they were subjected to the metabolic measurement procedure. After this procedure, the zygotes were cultured individually and evaluated for cleavage at 27, 30, 33, 36 and $42 \mathrm{~h}$ after insemination. The metabolic data were then analysed by time of cleavage.

In Expt $2 b$ (two replicates), presumptive zygotes were separated by time of first cleavage (at 27, 30, 33, 36 and $42 \mathrm{~h}$ after insemination) and cultured in groups. On day 8 , blastocysts from each group were removed from culture and washed twice in metabolic measurement medium before they were subjected to the metabolic measurement procedure.

The medium used during the measurement of embryo metabolism was SOF supplemented with $1.0 \mathrm{mmol}$ glucose $1^{-1}, 1.0 \mathrm{mmol}$ glutamine $1^{-1}$, and $10 \mathrm{mmol}$ Hepes $1^{-1}$. The technique used to measure embryo metabolism was as described by Rieger et al. (1992a), except for the composition of the medium. Mixtures of $\mathrm{D}-\left[5-{ }^{3} \mathrm{H}\right]$ glucose (specific activity $=$ 17.4 $\mathrm{Ci} \mathrm{mmol}^{-1}$, Amersham, Dublin) and L- $\left[{ }^{14} \mathrm{C}(\mathrm{U})\right]$ glutamine (specific activity $=277 \mathrm{mCi} \mathrm{mmol}^{-1}$, Amersham) were dried under nitrogen and taken up in metabolic measurement medium to give concentrations of $0.25 \mu \mathrm{Ci} \mu \mathrm{l}^{-1}$ of each radiolabelled substrate.

Individual embryos were taken up in $2 \mu \mathrm{l}$ metabolic measurement medium and placed in the cap of a sterile $2.5 \mathrm{ml}$ polypropylene screw-cap microtube with $2 \mu \mathrm{l}$ radiolabelled substrate mixture (total culture volume of $4 \mu \mathrm{l}$ ) to yield final total concentrations (labelled plus unlabelled) of $1.0 \mathrm{mmol}$ glucose $\mathrm{l}^{-1}$ and $1.5 \mathrm{mmol}$ glutamine $\mathrm{l}^{-1}$. The cap was fitted onto the tube quickly. The tubes had been loaded with $1.5 \mathrm{ml}$ of $25 \mathrm{mmol} \mathrm{NaHCO}_{3} 1^{-1}$ equilibrated with a gas mixture of $5 \% \quad \mathrm{O}_{2}, 5 \% \quad \mathrm{CO}_{2}$ and $90 \% \quad \mathrm{~N}_{2}$. Three sham preparations, containing all reagents but no embryo, were included for each preparation of labelled substrates. These served as controls for all non-specific counts due to machine background chemiluminescence, bacterial contamination, and spontaneous breakdown of the labelled substrate. After $3 \mathrm{~h}$, the cap was removed and the bicarbonate was mixed with $15 \mathrm{ml}$ scintillation fluid and counted for $5 \mathrm{~min}$ in a liquid scintillation counter. The total d.p.m. of labelled substrate was determined by mixing $2 \mu$ labelled substrate solution with $1.5 \mathrm{ml}$ of $25 \mathrm{mmol} \mathrm{NaHCO}_{3} \mathrm{l}^{-1}$, and counting in the same way. The amount of each substrate metabolized by each embryo was calculated according to Rieger et al. (1992a).

\section{Experiment 3: sex ratio of embryos}

Two separate sexing experiments were carried out. In Expt 3 a (three replicates), day 8 blastocysts $(n=258)$ originating from the different cleavage groups $(30,36$ and $42 \mathrm{~h}$ after insemination) were sexed using the procedure described by Pegoraro et al. (1998), whereas in Expt 3b (three replicates), embryos were lysed at the two-cell stage $(n=192)$ as they cleaved (that is, at $30,36,42$ and $48 \mathrm{~h}$ after insemination).

Briefly, embryos were lysed individually in an Eppendorf tube with $50 \mu \mathrm{l}$ buffer containing $50 \mathrm{mmol} \mathrm{KCl} \mathrm{l}^{-1}, 2.5 \mathrm{mmol}$ $\mathrm{MgCl}_{2} \mathrm{l}^{-1}, 0.1 \%(\mathrm{v} / \mathrm{v})$ Triton-X100, $150 \mu \mathrm{g}$ proteinase $\mathrm{K} \mathrm{ml}^{-1}$ and $15 \mathrm{mmol}$ Tris- $\mathrm{HCl} \mathrm{l}^{-1}, \mathrm{pH}$ 8.9. Tubes containing lysed embryos were incubated at $37^{\circ} \mathrm{C}$ for $45 \mathrm{~min}$, followed by incubation at $99^{\circ} \mathrm{C}$ for $10 \mathrm{~min}$ to inactivate proteinase $\mathrm{K}$.

Two pairs of flanking primers were used: the first pair against an autosomal sequence of $443 \mathrm{bp}$, indicating the presence of bovine genomic DNA; the second detected a sequence of $148 \mathrm{bp}$ specific to the bovine $\mathrm{Y}$ chromosome. Lysate $(9 \mu$ l) was amplified with $2 \mathrm{iu}$ Taq polymerase (Perkin Elmer, Courtaboeuf) in a final volume of $40 \mu \mathrm{l}$ containing 10 mmol Tris- $\mathrm{HCl} \mathrm{l}^{-1}$, $\mathrm{pH} \mathrm{8.3,50} \mathrm{mmol} \mathrm{KCl} \mathrm{l}^{-1}, 1.5 \mathrm{mmol} \mathrm{MgCl}_{2}$ $\mathrm{l}^{-1}, 0.1 \%(\mathrm{w} / \mathrm{v})$ gelatine, $0.2 \mathrm{mmol}$ of each $\mathrm{dNTP}^{-1}$ and $1 \mu \mathrm{mol}$ of each $\mathrm{Y}$ chromosome sequence-specific primer $1^{-1}$ and $0.08 \mu \mathrm{mol}$ of each autosomal sequence-specific primer $\mathrm{l}^{-1}$. The mixture was then amplified in a Perkin Elmer Cetus TC1 apparatus for 30 cycles; each cycle was composed of $20 \mathrm{~s}$ denaturation at $96^{\circ} \mathrm{C}, 20 \mathrm{~s}$ of hybridization and annealing at $60^{\circ} \mathrm{C}$ and 10 s elongation at $73^{\circ} \mathrm{C}$.

After amplification, $3 \mu \mathrm{l}$ gel loading solution $(0.08 \%(\mathrm{w} / \mathrm{v})$ Orange $\mathrm{G}, 30 \%$ (v/v) glycerol in $10 \times$ TAE $\left(4.84 \mathrm{~g}\right.$ Tris $1^{-1}, 1.142$ $\mathrm{ml}$ acetic acid $\left.\mathrm{l}^{-1}, 0.372 \mathrm{~g} \mathrm{EDTA}^{-1}\right)$ ) was added to the aqueous phase in each tube. Amplification products were resolved by electrophoresis on a $4.0 \%(\mathrm{w} / \mathrm{v})$ agarose gel (Nusieve:Seakem, $3: 1)$ prepared with a TAE buffer to which $0.3 \mu \mathrm{g}$ ethidium bromide $\mathrm{ml}^{-1}$ was added. Gels were subsequently visualized under UV illumination and photographed.

Embryos were considered to be female when only a clear $443 \mathrm{bp}$ product corresponding to the autosomic sequence was observed. When both the autosomic band and the band corresponding to the sequence of $\mathrm{Y}$ chromosome (148 bp) were observed or if a single clear 148 bp band was detected, the embryo was considered male. In all other cases (no visible bands, very weak signals, or bands in positions other than those expected), the sex of the embryo was not determined. Sex ratios of the various groups were compared with the expected ratio of $50 \%$.

\section{Experiment 4: embryo transfer}

Day 7 blastocysts ( $n=107$, two replicates) originating from oocytes that had cleaved by $30 \mathrm{~h}$ after insemination ( $n=55$, 'early' group) or between 30 and $36 \mathrm{~h}$ after insemination ( $n=52$, 'late' group) were transferred to synchronized recipients (one blastocyst per recipient). Heifers were synchronized using a controlled internal drug releasing (CIDR) device (InterAg, Hamilton) for 10 days; $15 \mathrm{mg}$ Luprostiol (Prosolvin; Intervet, Cambridge) was administered 2 days before CIDR device withdrawal. Pregnancy was diagnosed at day 35 by ultrasound scanning. Downloaded from Bioscientifica.com at 04/26/2023 11:10:50AM 
Table 1. Effect of time of first cleavage on development of bovine oocytes (Expt 1a)

\begin{tabular}{|c|c|c|c|c|c|c|c|c|}
\hline \multirow{2}{*}{$\begin{array}{l}\text { Time of first cleavage } \\
\text { (h after insemination) }\end{array}$} & \multicolumn{2}{|r|}{ Cleaved } & \multicolumn{3}{|c|}{ Day 8 blastocysts } & \multicolumn{2}{|c|}{ Hatched } & \multirow{2}{*}{$\begin{array}{l}\text { Number of cells } \\
\text { Mean } \pm \operatorname{SEM}(n)\end{array}$} \\
\hline & $n$ & Percentage of total & $n$ & Percentage & Percentage of total & $n$ & Percentage & \\
\hline 30 & 306 & 53.0 & 187 & $61.1^{\mathrm{a}}$ & 75.4 & 96 & 51.3 & $136 \pm 6(176)$ \\
\hline 36 & 170 & 29.5 & 59 & $34.7^{\mathrm{b}}$ & 23.8 & 35 & 59.3 & $120 \pm 7(59)$ \\
\hline 42 & 34 & 5.9 & 2 & $5.9^{c}$ & 0.8 & 0 & - & $75 \pm 15(2)$ \\
\hline 48 & 19 & 3.3 & 0 & - & - & - & - & - \\
\hline $\mathrm{NC}$ & 48 & 8.3 & 0 & - & - & - & - & - \\
\hline Total & 577 & 100.0 & 248 & 43.0 & 100.0 & 131 & 52.8 & $131 \pm 4(237)$ \\
\hline
\end{tabular}

${ }^{a b c}$ Values in the same column with different superscripts are significantly different $(P<0.0004)$.

NC: not cleaved at $42 \mathrm{~h}$ after insemination.

Table 2. Effect of time of first cleavage after insemination on the number of bovine blastocyst cells

\begin{tabular}{lccc}
\hline & \multicolumn{3}{c}{$\begin{array}{c}\text { Number of blastocyst cells } \\
\text { Mean } \pm \text { SEM }(n)\end{array}$} \\
\cline { 2 - 4 } & 30 h after insemination & 36 h after insemination & 42 h after insemination \\
\hline Hatched blastocyst & $189 \pm 8(87)^{\mathrm{a}}$ & $150 \pm 8(36)^{\mathrm{a} 2}$ & - \\
Blastocyst & $84 \pm 2(89)^{\mathrm{bl}}$ & $72 \pm 4(23)^{\mathrm{b} 2}$ & $75 \pm 15(2)$ \\
Total & $136 \pm 6(176)$ & $120 \pm 7(59)$ & $75 \pm 15(2)$ \\
\hline
\end{tabular}

ab Values in the same column with different superscripts are significantly different $(P<0.05)$.

${ }^{12}$ Values in the same row with different superscripts are significantly different $(P<0.05)$.

\section{Statistical analysis}

Treatment effects on cleavage rate, blastocyst yield and blastocyst hatching rate were determined by examining totals of all replicates using chi-squared analysis. Blastocyst rates were analysed by regression analyses as a function of the time of first cleavage. The number of cells (Expt 1a) was expressed as mean \pm SEM and totals were compared using the Mann-Whitney test. A $P$ value $<0.05$ was considered significant. Similarly, sex ratios were compared with the expected ratio of $50 \%$ using chi-squared analysis.

The effect of time of first cleavage on the metabolism of glucose and glutamine by individual zygotes was analysed by one-way analysis of variance, followed by Duncan's multiple-range tests to compare group means. The metabolism of glucose and glutamine by day 8 blastocysts was analysed by regression analyses of metabolism as a function of the time of first cleavage.

\section{Results}

\section{Experiment 1a}

When the presumptive zygotes were placed in culture at $24 \mathrm{~h}$ after insemination, none had cleaved, although several showed signs of imminent division. The number of zygotes that had cleaved at $30,36,42$ and $48 \mathrm{~h}$ after insemination was $306(53 \%), 170(29 \%), 34(6 \%)$ and $19(3 \%)$, respectively; 48 $(8 \%)$ remained uncleaved at $48 \mathrm{~h}$ after insemination (Table 1 ).

The overall cleavage rate assessed at $72 \mathrm{~h}$ after insemination was $94 \%(545 / 577)$, and $71 \%(410 / 577)$ of oocytes had reached the five- to eight-cell stages at this time. The overall blastocyst rate was $37 \%(213 / 577)$ at day 6 and $43 \%$
$(248 / 577)$ at day 8 . The hatching rate at day 8 was $53 \%$ (131/248).

Development to the blastocyst stage decreased markedly as the time from insemination to first cleavage increased $(P<$ $0.0001)$. Of the 306 zygotes that had cleaved by $30 \mathrm{~h}$ after insemination, $187(61 \%)$ developed to the blastocyst stage, of which $96(51 \%)$ hatched. In the 170 embryos that underwent cleavage between 30 and $36 \mathrm{~h}$ after insemination, $59(35 \%)$ reached the blastocyst stage, of which $35(59 \%)$ hatched. However, only two of the $34(6 \%)$ embryos that cleaved between 36 and $42 \mathrm{~h}$ after insemination developed to the blastocyst stage and none hatched. None of the embryos that underwent cleavage $42 \mathrm{~h}$ after insemination developed to the blastocyst stage.

Data on the number of blastocyst cells are presented (Table 2). Irrespective of the time of first cleavage, hatched blastocysts had significantly more cells than non-hatched blastocysts $(189 \pm 8$ versus $84 \pm 2, P<0.0001$, for oocytes that had cleaved at $30 \mathrm{~h}$ after insemination; $150 \pm 8$ versus $72 \pm 4$, $P<0.0001$, for embryos that cleaved at $36 \mathrm{~h}$ after insemination). In addition, hatched blastocysts originating from oocytes that cleaved at an earlier stage had a greater number of cells than those from late cleaving oocytes $(189 \pm 8$ versus $150 \pm 8$ for oocytes that cleaved at 30 and $36 \mathrm{~h}$ after insemination, respectively; $P<0.002$ ). The same observation was made in non-hatched blastocysts $(84 \pm 2$ versus $72 \pm 4$, for oocytes that cleaved at 30 and $36 \mathrm{~h}$ after insemination, respectively; $P<0.01$ ).

\section{Experiment $1 b$}

The overall cleavage rate was $85 \%(716 / 839)$ and the overall blastocyst yield was $39 \%(328 / 839)$ on the basis of the 
Table 3. Effect of time of first cleavage on development of bovine oocytes (Expt 1b)

\begin{tabular}{lrrrrrr}
\hline \multirow{2}{*}{$\begin{array}{l}\text { Time of first cleavage } \\
\text { (h after insemination) }\end{array}$} & \multicolumn{2}{c}{ Cleaved } & & \multicolumn{3}{c}{ Day 8 blastocysts } \\
\cline { 2 - 3 } \cline { 5 - 6 } & $n$ & Percentage of total & & Percentage & Percentage of total \\
\hline 27 & 350 & 41.7 & & 204 & $58.3^{\mathrm{a}}$ & 62.2 \\
30 & 200 & 23.8 & & 89 & $44.5^{\mathrm{b}}$ & 27.1 \\
33 & 76 & 9.1 & & 23 & $30.3^{\mathrm{c}}$ & 7.0 \\
36 & 26 & 3.1 & & 5 & $19.2^{\mathrm{c}}$ & 1.5 \\
42 & 51 & 6.1 & & 6 & $11.8^{\mathrm{c}}$ & 1.8 \\
48 & 13 & 1.5 & & 1 & $1.6^{\mathrm{c}}$ & 0.3 \\
$\mathrm{NC}$ & 123 & 14.7 & & 0 & - & - \\
Total & 839 & 100.0 & & 328 & 39.1 & 100.0 \\
\hline
\end{tabular}

abcValues in the same column with different superscripts are significantly different $(P<0.05)$. NC: not cleaved at $42 \mathrm{~h}$ after insemination.

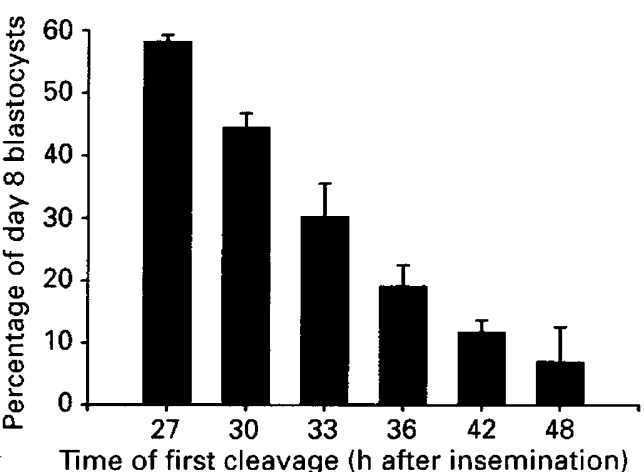

Fig. 1. Effect of time of first cleavage of bovine embryos after insemination on blastocyst yield at day 8 (from Expt 1b). Values are mean \pm SEM. The number of oocytes per group was $350,200,76,26$, 51 and 13 for zygotes that cleaved at $27,30,33,36,42$ and $48 \mathrm{~h}$ after insemination, respectively.

number of oocytes inseminated (Table 3). In accordance with the results from Expt 1a, there was a significant correlation $(r=0.97, P<0.01)$ between time of first cleavage and subsequent blastocyst yield, ranging from $58.3 \%$ in zygotes that cleaved by $27 \mathrm{~h}$ after insemination to only $7.7 \%$ in those cleaving between 42 and $48 \mathrm{~h}$ after insemination $(P<0.0001$, Fig. 1).

Of the total number of blastocysts produced, $62.2 \%$ were derived from zygotes that cleaved by $27 \mathrm{~h}$ after insemination and $89.3 \%$ from zygotes that underwent the first cleavage division by $30 \mathrm{~h}$ after insemination.

\section{Experiment 2}

There was no effect of time of first cleavage on the metabolism of glucose $(P>0.7)$ or glutamine $(P>0.7)$ by presumptive zygotes from 21 to $24 \mathrm{~h}$ after insemination (Expt $2 a$, Table 4). There was a significant negative relationship between time of first cleavage and both glucose $(r=-0.363$, $P<0.05)$ and glutamine $(r=-0.393, P<0.05)$ metabolism by day 8 blastocysts (Expt 2b, Table 5).

\section{Experiment 3}

Results obtained from sexing the embryos in the different cleavage groups are shown (Table 6). From a total of 258 blastocysts (Expt 3a), $161(62.4 \%)$ were male and $97(37.6 \%)$ were female $(P<0.001)$. The male:female sex ratio of all groups was significantly higher than the expected ratio of $50 \%$ (30 h after insemination: $60.6 \%, P<0.01 ; 36 \mathrm{~h}$ after insemination: $63.2 \%, P<0.025 ; 42 \mathrm{~h}$ after insemination: $87.5 \%, P<0.05)$. The sex ratio did not differ significantly among the different groups with respect to time of first cleavage.

At the two- to four-cell stages $(n=192)$, although the overall sex ratio differed significantly from the expected $1: 1$ (58.3\% male, $P<0.025)$, the ratio within groups was not significantly different from $1: 1$. As in Expt 3a, the sex ratio did not differ among groups.

\section{Experiment 4}

After transfer of a single blastocyst per recipient, the overall pregnancy rate was $43 \%(46 / 107)$. There was no difference in pregnancy rates between the two groups $(45 \%$ $(25 / 55)$ versus $40 \%(21 / 52)$ for zygotes that cleaved by 30 and $36 \mathrm{~h}$ after insemination, respectively).

\section{Discussion}

The results of the present study demonstrate that early cleaving bovine embryos selected according to the time of completion of the first division have greater development potential than late cleaving embryos, as determined by the proportion reaching the blastocyst stage after 8 days in culture. The overall rates of cleavage ( $>85 \%$ ), development to the blastocyst stage $(40 \%)$ and number of cells are consistent with those in other studies using the same procedures for embryo production (Carolan et al., 1995, Lonergan et al., 1996). These findings indicate that the increased manipulation involved in the present study did not affect subsequent embryo development. 
Table 4. Glucose and glutamine metabolism by bovine zygotes measured from 21 to $24 \mathrm{~h}$ after insemination (Expt 2a)

\begin{tabular}{lccc}
\hline $\begin{array}{l}\text { Time of first cleavage } \\
\text { (h after insemination) }\end{array}$ & Number of zygotes & Glucose metabolism $^{\mathrm{a}}$ & Glutamine metabolism $^{\text {a }}$ \\
\hline 27 & 3 & $2.0 \pm 1.3$ & $2.7 \pm 0.6$ \\
30 & 26 & $1.6 \pm 0.2$ & $2.6 \pm 0.2$ \\
33 & 12 & $1.7 \pm 0.4$ & $2.0 \pm 0.2$ \\
36 & 4 & $2.2 \pm 0.3$ & $3.0 \pm 0.4$ \\
42 & 7 & $1.5 \pm 0.3$ & $2.3 \pm 0.4$ \\
NC & 7 & $1.4 \pm 0.2$ & $2.5 \pm 0.2$ \\
Total & 59 & $1.6 \pm 0.1$ & $2.5 \pm 0.1$ \\
\hline
\end{tabular}

${ }^{a}$ Values are pmols per zygote per $3 \mathrm{~h}$, mean $\pm \mathrm{SEM}$.

$\mathrm{NC}$ : not cleaved at $42 \mathrm{~h}$ after insemination.

Table 5. Glucose and glutamine metabolism by day 8 bovine blastocysts (Expt $2 b$ )

\begin{tabular}{lccc}
\hline $\begin{array}{l}\text { Time of first cleavage } \\
\text { (h after insemination) }\end{array}$ & Number of blastocysts & Glucose metabolism $^{\mathrm{a}}$ & Glutamine metabolism $^{\mathrm{a}}$ \\
\hline 27 & 9 & $162 \pm 23$ & $3.4 \pm 0.5$ \\
30 & 9 & $140 \pm 32$ & $3.1 \pm 0.8$ \\
33 & 9 & $99 \pm 23$ & $2.0 \pm 0.6$ \\
36 & 5 & $100 \pm 44$ & $1.3 \pm 0.6$ \\
42 & 1 & 36 & 1.7 \\
Total & 33 & $126 \pm 14$ & $2.6 \pm 0.3$ \\
\hline
\end{tabular}

${ }^{a}$ Values are pmols per embryo per $3 \mathrm{~h}$, mean \pm SEM.

Table 6. Effect of time of first cleavage division on sex ratio of bovine embryos (Expt 3)

\begin{tabular}{|c|c|c|c|c|c|c|c|c|}
\hline \multirow{2}{*}{$\begin{array}{l}\text { Time of first cleavage } \\
\text { (h after insemination) }\end{array}$} & \multicolumn{4}{|c|}{ Sexed as blastocyst at day $8(\%)$} & \multicolumn{4}{|c|}{ Sexed as two- to four-cell embryo at $48 \mathrm{~h}$ after insemination (\%) } \\
\hline & $n$ & Male & Female & Sex ratio & $n$ & Male & Female & Sex ratio \\
\hline 30 & 155 & $94(60.6)$ & $61(39.3)$ & $1.54^{* *}$ & 99 & $58(58.6)$ & $41(41.4)$ & 1.41 \\
\hline 36 & 95 & $60(63.2)$ & $35(36.8)$ & $1.71^{* * *}$ & 69 & $39(56.5)$ & $30(43.5)$ & 1.30 \\
\hline 42 & 8 & $7(87.5)$ & $1(12.5)$ & $7.00^{* * * *}$ & 19 & $13(68.4)$ & $6(32.6)$ & 2.17 \\
\hline 48 & - & - & - & - & 5 & $2(40.0)$ & $3(60.0)$ & 0.67 \\
\hline Total & 258 & $161(62.4)$ & $97(37.6)$ & $1.66^{*}$ & 192 & $112(58.3)$ & $80(41.7)$ & $1.40^{* * *}$ \\
\hline
\end{tabular}

Treatments in which the sex ratio differed significantly from $50 \%$ are indicated (chi-squared test).

${ }^{*} P<0.001$; ${ }^{* *} P<0.01 ; * * * 00.025$; ${ }^{* * * P}<0.05$.

The time points chosen were on the basis of previous studies indicating that the first cleavage of bovine zygotes in vitro occurs between 26 and $32 \mathrm{~h}$ after insemination (Barnes and Eyestone, 1990; Van Soom et al., 1992; Yadav et al., 1993). This was also the case under the conditions of the present study, in which no zygotes cleaved before $24 \mathrm{~h}$ after insemination. Approximately $42 \%$ of zygotes underwent the first cleavage division between 24 and $27 \mathrm{~h}$ after insemination. These represented the most competent oocytes in terms of developmental ability in vitro, and are comparable with the situation in vivo in which the first cleavage occurs at 24-28 $\mathrm{h}$ after ovulation in non-superovulated cows (Thibault et al., 1987). More than $75 \%$ of zygotes underwent the first cleavage by $36 \mathrm{~h}$ after insemination, and these embryos accounted for more than $90 \%$ of all blastocysts produced.

The factors that determine the ability of a zygote to cleave early rather than late are unclear. Although culture conditions influence the kinetics of early development (Pinyopummintr and Bavister, 1994; Van Langendonckt et al., 1997), the role of genetic factors should not be underestimated. In mice, a gene has been identified that controls the rate of preimplantation cleavage division and subsequent embryo survival (Ped: preimplantation embryo development) (for a review, see Warner et al., 1998). Two alleles of the Ped gene have been identified: Ped fast and Ped slow. Ped fast mice have a faster rate of preimplantation development, larger litter sizes and are significantly larger at birth and at weaning. The Qa-2 antigen, the product of the Ped gene, is expressed in early mouse embryos, beginning at the two-cell stage, and is known to be present on the surface of mouse blastocysts (McElhinny and Warner, 1997). McElhinny et al. (1998) reported that Ped fast blastocysts contain a significantly greater number of cells in both the 
inner cell mass and the trophectoderm than Ped slow blastocysts, and that this phenotype is related directly to the expression of the Qa-2 antigen in both lineages. It is possible that such a gene is involved in the differential development rates in bovine embryos.

In addition to maternal influences transmitted via the oocyte, paternal influences may have an effect on development. It is well established that the bull can have a major effect on the outcome in an IVF programme (Hillery et al., 1990; Marquant-Le Guienne et al., 1990). The difference among bulls is apparent from the time of first cleavage (P. Lonergan, unpublished observation).

As well as positive influences, there may be negative influences involved in regulating the rate of development. Slimane et al. (1998) reported that $77 \%$ of two-cell bovine embryos that cleaved by $24-26 \mathrm{~h}$ after insemination were normal compared with only $44 \%$ of those that remained at the two-cell stage at $48 \mathrm{~h}$ after insemination, as determined by fluorescence in situ hybridization (FISH) with a probe specific for chromosome 1. It was suggested that monosomy and defective chromosome segregation at first mitosis are the main causes for delayed first cleavage. Similarly, Yadav et al. (1993) reported a higher incidence of chromosomal abnormalities in late cleaving compared with early cleaving bovine embryos. Other factors may also be involved, for example, Nolan et al. (1998) showed that factors such as nutritional treatment of the donor can influence the timing of blastocyst formation.

Significant changes in metabolic activity occur during development from the two-cell to the blastocyst stage in bovine embryos produced in vitro. Glucose metabolism is low until the 8- to 16-cell stages, and then increases continuously to the expanded blastocyst stage. In contrast, glutamine metabolism is high at the early cleavage stages, decreases to a minimum at the blastocyst stage and increases during blastocyst expansion (Rieger et al., 1992a,b).

The overall mean metabolism of glucose by presumptive zygotes at 21-24 h after insemination (1.6 \pm 0.1 pmols per $3 \mathrm{~h}$ ) was consistent with other reports of glucose metabolism by mature oocytes (Rieger and Loskutoff, 1994) and two-cell embryos (Rieger et al., 1992a,b). Mean glutamine metabolism by presumptive zygotes $(2.5 \pm 0.1$ pmols per $3 \mathrm{~h})$ was intermediate to previous measurements for mature oocytes (Rieger and Loskutoff, 1994) and two-cell embryos (Rieger et al., $1992 \mathrm{a}, \mathrm{b})$. Although incubation in the metabolism medium for $3 \mathrm{~h}$ may have retarded the subsequent development of zygotes after they were returned to culture, there was no relationship between the metabolic activity of presumptive zygotes at $21-24 \mathrm{~h}$ after insemination and the time of first cleavage (27-42 $\mathrm{h}$ after insemination). This may indicate that the first cleavage is independent of the metabolic activity of the zygote, or that the metabolic requirements for first cleavage have been fulfilled before $21-24 \mathrm{~h}$ after insemination.

Mean glucose metabolism by day 8 blastocysts $(126 \pm 14$ pmols per $3 \mathrm{~h}$ ) was also consistent with other studies (Rieger et al., 1992b), whereas mean glutamine metabolism by day 8 blastocysts $(2.6 \pm 0.3$ pmols per $3 \mathrm{~h}$ ) was lower than that observed in other studies (Rieger et al., 1992b). The reasons for this are unclear, but may be related to differences in the source of oocytes or the embryo culture techniques. The significant negative relationship between the time of first cleavage and both glucose and glutamine metabolism by day 8 blastocysts indicates that the mechanisms responsible for early first cleavage, or the increased time of development between first cleavage and day 8 can affect the metabolic activity of the blastocyst. However, the possibility that the observed differences were due to differences in the number of cells cannot be discounted.

Several studies demonstrated a relationship between development rate and sex of in vitro produced mammalian embryos, and male embryos developed faster than female embryos (mouse: Tsunoda et al., 1985; Burgoyne, 1993; Valdivia et al., 1993; Zwingman et al., 1993; Peippo and Bredbacka, 1995; cattle: Avery et al., 1989, 1991; Xu et al., 1992; Yadav et al., 1993; Dufour et al., 1994; Carvalho et al., 1996; sheep: Bernardi and Delouis, 1996; Catt et al., 1997; pigs: Cassar et al., 1994; human: Ray et al., 1995). In contrast, Grisart et al. (1995) did not find an alteration in the sex ratio of bovine embryos cultured in serum-free oviduct cellconditioned medium. Kaminski et al. (1996) concluded that pig embryonic development occurs at a rate determined by the uterine environment and not by the sex of the conceptus, which is in contrast to the results of Cassar et al. (1994). In the present study, significantly more male embryos were observed when sexing was carried out at the blastocyst stage (Expt 4a). This observation was not related to the time of first cleavage of the embryo. In contrast, when embryos were sexed at the two-cell stage, although the overall sex ratio was skewed, the deviation in sex ratio was not as marked as on day 8 . This may indicate that differences between male and female embryos in terms of developmental ability are due to events that occur after cleavage. Similar results were reported by Dufour et al. (1994) in a study in which fast- and slowcleaving embryos were separated at $48 \mathrm{~h}$ after insemination. There was no difference in sex ratio between the two groups at this stage. However, after 8 days of culture, fast-developing embryos showed a skewed sex ratio in favour of males, indicating that factors present after fertilization are involved.

Male and female embryos have different metabolic requirements and utilization rates in vitro (Tiffen et al., 1991; Ray et al., 1995). It has been proposed that these metabolic differences could be used to predict the sex and viability of embryos (Rieger, 1984). These differences may occur as early as the first cleavage in bovine (Dominko and First, 1993) and human (Ray et al., 1995) embryos. Bredbacka and Bredbacka (1996) reported that male embryos develop faster than female embryos only in the presence of exogenous glucose and explained this fact by differential gene expression in male and female embryos.

Obtaining live offspring after embryo transfer is the ultimate test of a successful embryo production system. To date, the in vivo viability of embryos derived from oocytes that cleaved at different times has not been investigated in cattle. However, there is indirect evidence from the study of Hasler et al. (1995), in which higher pregnancy rates were observed for day 7 fresh blastocysts compared with day $8(56 \%$ versus $43 \%)$. This difference was greater when frozen embryos were used (42 versus $20 \%$ ), indicating that the fastest developing embryos were more tolerant of the cryopreservation procedures than the embryos that 
developed more slowly. In addition, McKiernan and Bavister (1994) reported that one-cell hamster embryos that developed to the eight-cell stage by $58 \mathrm{~h}$ after egg activation produced almost twice as many day 14 fetuses $(51 \%)$ as embryos that had reached the four-cell stage by $58 \mathrm{~h}(26 \%)$. It was proposed that faster developing embryos are more viable than embryos that develop more slowly. In the present study, no difference was observed in pregnancy rate between blastocysts derived from early cleaving and late cleaving zygotes. Embryos from the two extremes, that is, those cleaving by $27 \mathrm{~h}$ after insemination and those cleaving at 42-48 $\mathrm{h}$ after insemination, were not compared. However, most of the total number of blastocysts originated from oocytes that cleaved by $36 \mathrm{~h}$ after insemination (approximately $90 \%$ ), and those derived from the $42-48 \mathrm{~h}$ group would not be selected for transfer in routine practice. This finding indicates that morphological grading at day 7 is an acceptable method of selecting embryos for transfer.

In conclusion, a non-invasive method of assessing oocyte and embryo quality would be invaluable in embryo transfer by allowing the selection of oocytes and embryos with the highest probability of producing live offspring after transfer.

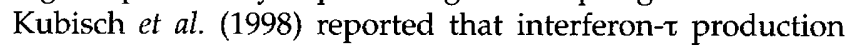
was lower in early forming bovine blastocysts compared with those that formed at a later stage. It was suggested that measurement of interferon- $\tau$ production coupled with visual assessment of morphology may provide a means of distinguishing between high and low quality blastocysts. The results of the present study show that the timing of early cleavage, particularly the time interval from insemination to first cleavage, is of critical importance in this respect, offering a non-invasive assessment of embryo viability before transfer or cryopreservation. This also has implications for human assisted reproduction in which embryos are usually transferred at the four- to six-cell stage. In such cases, considering the kinetics of cleavage could be invaluable in improving pregnancy rates.

The reasons why two morphologically identical two-cell embryos that differ only in the time between insemination and first cleavage, and which show apparently similar protein synthesis patterns and metabolism should display such a marked difference in development remain to be elucidated. These differences in developmental ability may provide a model for the study of developmental competence acquisition in mammalian oocytes and constitute a potentially useful tool for studying gene expression in early embryos.

P. Lonergan was financed partly by a grant from the European Commission (Contract Number BIO 4CT 975073) and partly by a PostDoctoral Fellowship from Forbairt (PD/97/013). Part of this research was supported by the US-Ireland Grant of the Department of Agriculture and Food. The authors gratefully acknowledge the assistance of Mary Wade, Pat Duffy, Hugh McGovern and Vivian Gath.

\section{References}

Avery B, Bak A and Schmidt M (1989) Differential cleavage rates and sex determination in bovine embryos Theriogenology 32 139-147

Avery B, Madison V and Greve T (1991) Sex and development in bovine in vitro fertilized embryos Theriogenology 35 953-963
Barnes FL and Eyestone WH (1990) Early cleavage and the maternal zygotic transition in bovine embryos Theriogenology 33 141-152

Bavister BD, Boatman DE, Leibfried ML, Loose M and Vernon MW (1983) Fertilization and cleavage of rhesus monkey oocytes in vitro. Biology of Reproduction $28983-999$

Bernardi ML and Delouis C (1996) Sex-related differences in the developmental rate of in vitro matured/in vitro fertilized ovine embryos Human Reproduction 11 621-626

Bredbacka K and Bredbacka P (1996) Glucose controls sex-related growth rate differences of bovine embryos produced in vitro. Journal of Reproduction and Fertility 106 169-172

Burgoyne PS (1993) A Y-chromosomal effect on blastocyst cell number in mice Development 117 341-345

Carolan C, Lonergan P, Van Langendonckt A and Mermillod P (1995) Factors affecting bovine embryo development in synthetic oviduct fluid following oocyte maturation and fertilization in vitro. Theriogenology 43 1115-1128

Carvalho RV, Del Campo MR, Palasz AT, Plante Y and Mapletoft RJ (1996) Survival rates and sex ratio of bovine IVF embryos frozen at different developmental stages on day 7 Theriogenology $45489-498$

Cassar G, King WA and King GJ (1994) Influence of sex on early growth of pig conceptuses Journal of Reproduction and Fertility 101 317-329

Catt SL, O'Brien JK, Maxwell WMC and Evans G (1997) Effects of rate of development of in vitro produced ovine embryos on sex ratio and in vivo survival after embryo transfer Theriogenology 48 1369-1378

Dominko T and First NL (1992) Kinetics of bovine oocyte maturation allows selection for developmental competence and is affected by gonadotropins Theriogenology 37203 (Abstract)

Dominko T and First NL (1993) Male predominance of bovine embryos can be observed at the 2-cell stage Biology of Reproduction 48 Supplement 1168 (Abstract)

Dufour E, Marquant-Le Guienne B, Thuard JM, Esposito L and Thibier M (1994) Sex related differential development rate of in vitro produced bovine embryos 10th Annual Meeting of the European Embryo Transfer Association Lyon, 9-10 September, 166 (Abstract)

Gordon I (1994) Laboratory production of cattle embryos. In Biotechnology in Agriculture $11 \mathrm{CAB}$ International, Wallingford

Grisart B, Massip A and Dessy F (1994) Cinematographic analysis of bovine embryo development in serum-free oviduct-conditioned medium Journal of Reproduction and Fertility $101257-264$

Grisart B, Massip A, Collette L and Dessy F (1995) The sex ratio of bovine embryos produced in serum-free oviduct cell-conditioned medium is not altered Theriogenology 43 1097-1106

Hasler JF, Henderson WB, Hurtgen PJ et al. (1995) Production, freezing and transfer of bovine IVF-embryos and subsequent calving results Theriogenology 43 141-152

Hillery FL, Parrish JJ and First NL (1990) Bull specific effect on fertilization and embryo development in vitro. Theriogenology 33249 (Abstract)

Itagaki Y, Kimura N, Yamanaka M and Muneta Y (1997) Differences in early cleavage rates of in vitro produced bovine embryos classified according to completion of their first cleavage Journal of Reproduction and Development 43 $53-58$

Kaminski MA, Ford SP, Youngs CR and Conley AJ (1996) Lack of effect of sex on pig embryonic development in vivo. Journal of Reproduction and Fertility $106107-110$

Kubisch HM, Larson MA and Roberts RM (1998) Relationship between age of blastocyst formation and interferon- $\tau$ secretion by in vitro-derived bovine embryos Molecular Reproduction and Development 49 254-260

Lelaidier C, de Ziegler D, Frietas S et al. (1995) Endometrium preparation with exogenous estradiol and progesterone for the transfer of cryopreserved blastocysts Fertility and Sterility 63 919-921

Lonergan P, Fair T and Gordon I (1992) Effect of time of transfer to granulosa cell monolayer and cell stage at 48 hours post-insemination on bovine oocyte development following IVM/IVF/IVC 8th Meeting of the European Embryo Transfer Association Lyon, 11-12 September, 136 (Abstract)

Lonergan P, Monaghan P, Rizos D, Boland MP and Gordon I (1994) Effect of follicle size on bovine oocyte quality and developmental competence following maturation, fertilization and culture in vitro. Molecular Reproduction and Development 37 48-53

Lonergan P, Carolan C, Thuard J-M, Marquant-Le Guienne B and Mermillod P (1995) Embryo transfer and sex ratio of resulting calves following bovine embryo production in vitro. 11th Meeting of the European Embryo Transfer Association Hannover, 11-12 September, 136 (Abstract)

Lonergan P, Carolan C, Van Langendonckt A, Donnay I, Khatir H and 
Mermillod P (1996) The role of epidermal growth factor in bovine oocyte maturation and preimplantation embryo development in vitro. Biology of Reproduction 54 1420-1429

McCaffrey C, McEvoy TG, Diskin MG, Gwazdauskas FC, Kane MT and Sreenan JM (1991) Successful co-culture of 1-4 cell cattle ova to the morula or blastocyst stage Journal of Reproduction and Fertility 91 119-124

McElhinny S and Warner CM (1997) Detection of major histocompatibility complex class I antigens on the surface of a single murine blastocyst by immuno-PCR Biotechniques $23660-662$

McElhinny S, Kadow N and Warner CM (1998) The expression pattern of the Qa-2 antigen in mouse preimplantation embryos and its correlation with the Ped gene genotype Molecular Human Reproduction 4 966-971

McKiernan SH and Bavister BD (1994) Timing of development is a critical parameter for predicting successful embryogenesis Human Reproduction 9 2123-2129

Marquant-Le Guienne B, Gerard M, Solari A and Thibault C (1989) In vitro culture of bovine eggs fertilized in vivo or in vitro. Reproduction, Nutrition and Development 29559-568

Marquant-Le Guienne B, Humblot P, Thibier M and Thibault C (1990) Evaluation of bull semen fertility by homologous in vitro fertilization tests Reproduction Nutrition and Development 30 259-266

Nolan R, O'Callaghan D, Duby RT, Lonergan P and Boland MP (1998) Influence of short-term nutrient changes on follicle growth and embryo production following superovulation in beef heifers Theriogenology $\mathbf{5 0}$ 1263-1274

Pavlok A, Lucas-Hahn A and Niemann H (1992) Fertilization and developmental competence of bovine oocytes derived from different categories of antral follicles Molecular Reproduction and Development 31 63-67

Pegoraro LMC, Thuard JM, Delalleau N, Guerin B, Deschamps JC Marquant-Le Guienne B and Humblot P (1998) Comparison of sex ratio and cell number of IVM-IVF bovine blastocysts co-cultured with bovine oviduct epithelial cells or with vero cells Theriogenology 49 1579-1590

Peippo J and Bredbacka $P(1995)$ Sex-related growth rate differences in mouse preimplantation embryos in vivo and in vitro. Molecular Reproduction and Development $4056-61$

Pinyopummintr T and Bavister BD (1994) Development of bovine embryos in a cell-free culture medium: effects of type of serum, timing of its inclusion and heat inactivation Theriogenology 41 1241-1249

Plante L, Plante C, Sheperd DL and King WA (1994) Cleavage and ${ }^{3} \mathrm{H}$-uridine incorporation in bovine embryos of high in vitro developmental potential Molecular Reproduction and Development 39 375-383

Ray PF, Conaghan J, Winston RML and Handyside AH (1995) Increased number of cells and metabolic activity in male human preimplantation embryos following in vitro fertilization Journal of Reproduction and Fertility 104 165-171

Rieger D (1984) The measurement of metabolic activity as an approach to evaluating viability and diagnosing sex in early embryos Theriogenology 21 138-149

Rieger D and Loskutoff NM (1994) Changes in the metabolism of glucose, pyruvate, glutamine and glycine during maturation of cattle oocytes in vitro. Journal of Reproduction and Fertility 100 257-262

Rieger D, Loskutoff NM and Betteridge KJ (1992a) Developmentally related changes in the metabolism of glucose and glutamine by cattle embryos produced and co-cultured in vitro. Journal of Reproduction and Fertility 95 585-595
Rieger D, Loskutoff NM and Betteridge KJ (1992b) Developmentally related changes in the uptake and metabolism of glucose, glutamine and pyruvate by cattle embryos produced in vitro. Reproduction Fertility and Development 4 547-557

Sakkas D, Shoukir Y, Chardonnens D, Bianchi PG and Campana A (1998) Early cleavage of human embryos to the two-cell stage after intracytoplasmic sperm injection as an indicator of embryo viability Human Reproduction 13 182-187

Shoukir Y, Chardonnens D, Campana A, Bischof P and Sakkas D (1998) The rate of development and time of transfer play different roles in influencing the viability of human blastocysts Human Reproduction 13 676-681

Slimane W, Hayes H, Eggen A, Peynot N and Renard JP (1998) Incidence of chromosomal abnormalities in two cell bovine IVF embryos after normal or delayed cleavage 14th Meeting of the European Embryo Transfer Association Venice, 11-12 September, 250 (Abstract)

Thibault C, Szollosi D and Gerard M (1987) Mammalian oocyte maturation Reproduction Nutrition and Development 27 865-896

Tiffen G, Rieger D, Betteridge KJ, Yadav BR and King WA (1991) Glucose and glutamine metabolism in pre-attachment cattle embryos in relation to sex and stage of development journal of Reproduction and Fertility 93 125-132

Totey SM, Daliri M, Appa Rao KBC, Pawshe CH, Taneja M and Chillar RS (1996) Differential cleavage and developmental rates and their correlation with cell numbers and sex ratios in buffalo embryos generated in vitro. Theriogenology 45 521-533

Tsunoda $Y$, Tokunaga $T$ and Sugle $T$ (1985) Altered sex ratio of live young after transfer of fast- and slow-developing mouse embryos Gamete Research 12 301-304

Valdivia RPA, Kuneida T, Azuma S and Toyoda Y (1993) PCR sexing and developmental rate differences in preimplantation mouse embryos fertilized and cultured in vitro. Molecular Reproduction and Development 35 $121-126$

van der Westerlaken LAJ, van der Schans A, Eyestone WH and de Boer HA (1994) Kinetics of first polar body extrusion and the effect of time of stripping of the cumulus and time of insemination on developmental competence of bovine oocytes Theriogenology 42 361-370

Van Langendonckt A, Donnay I, Schuurbiers N, Auquier P, Carolan C, Massip A and Dessy F (1997) Effects of supplementation with fetal calf serum on development of bovine embryos in synthetic oviduct fluid medium journal of Reproduction and Fertility 109 87-93

Van Soom A, Van Vlaenderen I, Mahmoudzadeh AR, Deluyker $\mathrm{H}$ and de Kruif A (1992) Compaction rate of in vitro fertilized bovine embryos related to the interval from insemination to first cleavage Theriogenology 38 905-919

Warner CM, McElhinny S, Wu L, Cieluch C, Ke X, Cao W, Tang C and Exley G (1998) Role of the Ped gene and apoptosis genes in control of preimplantation development Journal of Assisted Reproduction and Genetics 15 331-337

Xu KP, Yadav BR, King WA and Betteridge KJ (1992) Sex-related differences in developmental rates of bovine embryos produced and cultured in vitro. Molecular Reproduction and Development 31 249-252

Yadav BR, King WA and Betteridge KJ (1993) Relationships between the completion of first cleavage and chromosomal complement, sex, and developmental rates of bovine embryos generated in vitro. Molecular Reproduction and Development 36 434-439

Zwingman T, Erickson RP, Boyer T and Ao A (1993) Transcription of the sexdetermining region genes Sry and Zfy in the mouse preimplantation embryo Proceedings National Academy of Science USA 90 814-817 